\title{
PEMBERDAYAAN MASYARAKAT MELALUI BUDIDAYA TANAMAN CABAI MERAH DALAM POT
}

\section{COMMUNITY EMPOWERMENT THROUGH RED CHILI CULTIVATION IN POT}

\author{
Warnita $^{1)}$ dan Aisman ${ }^{2)}$ \\ ${ }^{1)}$ Fakultas Pertanian Universitas Andalas \\ ${ }^{2)}$ Fakultas Teknologi Pertanian Universitas Andalas \\ email: warnita_imu@yahoo.com¹ dan aisman64@yahoo.com
}

\begin{abstract}
ABSTRAK
Kelurahan Limau Manih Kota Padang merupakan kawasan pertanian yang cukup luas, dimana umumnya petani menanam padi, jagung dan sayur - sayuran. Salah satu sayuran yang dibudidayakan adalah cabai merah. Permintaan terhadap cabai merah terus meningkat dan harganya berfluktuasi. Flukasi harga yang tinggi menimbulkan masalah bagi masyarakat, apalagi cabai merah sangat dibutuhkan. Oleh karena itu perlu dilakukan penanaman cabai merah dalam pot di sekitar pekarangan rumah. Tujuan dari KKN-PPM adalah untuk mendorong empati mahasiswa dan dapat memberikan sumbangsih bagi penyelesaian persoalan yang ada di masyarakat dengan mengaplikasikan hasil-hasil penelitian untuk meningkatkan hasil cabai merah dalam pot. Metode yang diterapkan melalui pendekatan terhadap masyarakat petani dan pemuka masyarakat dengan menumbuhkembangkan dan memotivasi kelompok tani sehingga program KKN-PPM ini dapat diterima dengan baik oleh masyarakat. Kegiatan yang dilakukan berupa : 1) penyuluhan, 2) pelatihan dan 3) demontrasi/ percontohan. Hasil yang dicapai dari kegiatan program KKN-PPM ini adalah : 1) Meningkatnya kepedulian dan empati mahasiswa terhadap permasalahan ekonomi dan sosial sehingga dapat meningkatkan pendapatan warga masyarakat; 2). Adanya respon positif yang diberikan warga masyarakat berupa partisipasi aktif dan antusias mengikuti kegiatan budidaya cabai merah dalam pot dari awal sampai akhir pelaksanaan.
\end{abstract}

Kata kunci : Cabai merah, Pemberdayaan, Demonstrasi, Masyarakat, Pot

\begin{abstract}
Limau Manih village is a large agricultural area, so farmers generally grow rice, maize and vegetables. One such vegetable is a red chili which is a daily necessity. The demand for red peppers continues to increase and their prices fluctuate. High price fluctuations cause problems for the community, especially chilli is needed. Therefore it is necessary to plant red pepper in pots around the yard of the house. The purpose of KKN-PPM is to encourage empathy students and can contribute to solving problems that exist in the community by applying the results of research to improve the results of red pepper in pots. Method applied by approach to farmer community and community leaders by cultivating and motivating farmer group so that KKN - PPM program can be accepted well by society. The activities are: 1) counseling, 2) training and 3) demonstration / demonstration. The results of this $K K N$ PPM program are: 1) Increased awareness and empathy of students on economic and social issues so as to increase the income of the community; 2). Positive response given by the community in the form of active and enthusiastic participation following the activity of red chili cultivation in pot from beginning to end of implementation
\end{abstract}

Keywords: red chili, empowerment, demontration, community, pot 


\section{PENDAHULUAN}

Kelurahan Limau Manih adalah kelurahan dimana kampus Universitas Andalas berada dan merupakan kawasan pertanian yang cukup luas di Kota Padang. Masyarakat Kelurahan Limau Manih banyak membudidayakan tanaman padi, jagung, dan sayur-sayuran termasuk cabai merah.

Cabai merah (Capsicum annum) merupakan salah satu jenis sayuran penting yang bernilai ekonomi tinggi dan cocok dikembangkan di di daerah ini. Cabai merah sebagian besar digunakan untuk konsumsi rumah tangga dan sebagiannya diperdagangkan dalam bentuk cabai merah segar, cabai merah kering, saus, dan bubuk cabai merah.

Dari kelompok tanaman sayuran, cabai merah adalah termasuk yang volume peredarannya di pasar ada dalam skala besar. Harga cabai merah sering berflukasi terutama di hari besar keagamaan dan akhir tahun. Fluktuasi harga yang tinggi menimbulkan masalah keterjangkauan oleh masyarakat serta mendongkrak angka inflasi.

Tanaman Cabai merah adalah tanaman perdu dengan rasa buah pedas yang disebabkan oleh kandungan capsaicin. Secara umum cabai merah memiliki banyak kandungan gizi dan vitamin, diantaranya kalori, protein, lemak, karbohidrat, kalsium, vitamin A, B1 dan vitamin C (Prayudi, 2010)[1]. Selain itu cabai merah mengandung kapsaisin, dihidrokapsaisin, zat warna kapsantin, karoten, kapsarubin, zeasantin, kriptosantin, clan lutein, mineral, seperti zat besi, kalium, kalsium, fosfor, dan niasin.

Kebutuhan cabai merah yang meningkat seiring dengan pertambahan penduduk dan berkembangnya produk olahan cabai merah menyebabkan harga cabai merah berfluktuasi. Alternatif penyediaan cabai merah bagi masyarakat pada saat terjadi fluktuasi harga yang tinggi adalah dengan penanaman cabai merah di dalam pot di pekarangan rumah. Penanaman cabai merah di dalam pot tidaklah membutuhkan areal yang luas, sehingga hampir setiap rumah tangga dapat melakukannya. Hasil panen cabai merah dalam pot diharapkan dapat memenuhi kebutuhan keluarga sehinga mengurangi pengeluaran rumah tangga.

Cabai merah di dalam pot, disamping bernilai komersial juga menarik bila dijadikan sebagai tanaman hias. Tanaman cabai merah merupakan salah satu tanaman hias buah yang biasa ditanam dalam pot dan dapat berfungsi baik sebagai tanaman hias dalam ruang dan di luar ruangan (Setiadi, 2005)[2]. Purwono (2003) [3] menambahkan bahwa keuntungan menanam cabai merah di dalam pot adalah perawatan tanaman menjadi lebih mudah karena syarat tumbuh tanaman dapat dipenuhi, dan praktis karena tanaman dalam pot mudah dipindahkan dari satu tempat ke tempat yang lain.

Budidaya tanaman cabai merah dalam 
pot juga merupakan alternatif pengambangan tanaman cabai merah di lahan sempit seperti di daerah perkotaan. Hal yang perlu dipertimbangkan dalam budidaya tanaman cabai merah pot adalah pemilhan bibit, persemaian bibit, media tanam, pemilihan pot, penamanan, perawatan dan panen.

Banyak alternatif media selain tanah yang mulai digunakan sebagai media tanam dalam pot. Hal yang menjadi pertimbangan konsumen dalam memilih media yang akan digunakan, diantaranya ketersediaan bahan media, harga, dan mudah tidaknya media ditangani.

Sumarni dan Rosliani (2001)[4] menyatakan bahwa media arang sekam mudah didapat dan mempunyai sifat fisik dan kimia yang baik sebagai media tumbuh. Menurut Wuryaningsih et al. (2001) [5] tanaman krisan pot yang ditumbuhkan pada media kokopit menghasilkan tinggi tanaman dan diameter tanaman lebih besar dibandingkan pada media serbuk gergaji. Menurut Warnita et al. (2015) [6], media terbaik untuk Amarylis adalah tanah, pasir, dan pupuk kandang sapi (1:1:1, v/v). Selanjutnya Warnita dan Herawati (2017) [7] menyatakan media tanam yang terdiri atas tanah, pasir, dan pupuk kandang dengan perbandingan 1:1:1 (v/v) baik untuk pertumbuhan tanaman anthurium. Komposisi media tanah : pasir : sampah kota : 1:1:1 merupakan media terbaik untuk pertumbuhan jumlah daun, jumlah bunga, bobot segar dan bobot kering tanaman krisan (Warnita et al, 2017) [8].

Komposisi media arang sekam:tanah: kompos (1:2:1) dan komposisi media pasir malang : tanah : kompos (2:2:1) merupakan media yang baik untuk menstimulasi pertumbuhan tunas pada Sansevieria trifasciata Prain "Laurentii" jenis variegata (Suharsi dan Andiani, 2013)[9]. Pemanfaatan bahan organik arang sekam padi sebagai komposit media top soil mampu memberikan respons yang lebih baik bagi pertumbuhan bibit cempaka wasian dibandingkan dengan penggunaan bahan organik cocopeat (Irawan dan Kafiar, 2015) [10].

Selain itu, bahan organik diketahui berfungsi sebagai pupuk yang berguna untuk menunjang pertumbuhan tanaman dan menekan kehilangan hasil yang diakibatkan oleh serangan Organisme Pengganggu Tumbuhan (OPT) serta dapat menjaga kualitas hasil pertanian (BPTPH, 2010)[11]. Beberapa kelebihan dari bahan organik adalah berbahan baku alami dan ramah lingkungan yang mampu menekan serangan penyakit tular tanah yang dapat menyerang tanaman cabai merah.

Fatmawati (2009) [12] menyatakan bahwa kotoran ternak setelah terinkubasi merupakan bahan yang mengandung banyak unsur hara. Keuntungan penambahan mikroorganisme efektif sebagai bioaktivator adalah diantaranya; mempercepat dekomposisi bahan-bahan organik secara 
fermentasi, melarutkan P (Phospat) yang tidak tersedia menjadi bentuk $\mathrm{P}$ yang tersedia bagi tanaman, mengikat nitrogen udara, menghasilkan berbagai enzim dan hormon bagi senyawa bioaktif untuk pertumbuhan.

Umumnya pada budidaya tanaman cabai merah, petani sangat tergantung dan mengandalkan pupuk kimia seperti urea dan NPK sebagai sumber nutrisi untuk meningkatkan pertumbuhan dan hasil. Menurut Adijaya dan Sugiarta (2013) [13] pada beberapa kasus dilaporkan pupuk kimia ini digunakan secara berlebihan sehingga berdampak terhadap rentannya tanaman terhadap serangan hama penyakit. Disamping itu penggunaan pestisida kimia yang berlebihan juga berdampak terhadap meningkatnya kekebalan hama cabai merah.

Efisiensi pemupukan merupakan hal yang sangat penting bagi usaha pertanian mengingat tingginya kehilangan yang diakibatkan proses-proses dalam tanah seperti aliran pemupukan, pencucian, evaporasi, fiksasi dan imobilisasi. Meningkatnya harga pupuk buatan, juga jadi pertimbangan agar penggunaan pupuk buatan secara perlahan-lahan harus dikurangi dan diganti dengan pupuk organik dan pupuk hayati.

Masalah yang dihadapi petani di Kelurahan Limau Manih adalah masalah pupuk yang tidak tersedia sesuai dengan kebutuhan masyarakat. Sering terjadi kelangkaan pupuk karena pupuk subsidi hilang di pasaran, sehingga petani sulit untuk mempertahankan produksinya. Rencana pemerintah mengurangi/menghapus subsidi pupuk secara bertahap, akan menyebabkan petani makin kesulitan untuk memenuhi kebutuhan pupuknya.

Salah satu alternatif yang dapat memecahkan masalah kelangkaan pupuk ini adalah menggunakan pupuk organik seperti kotoran ternak dan kompos, dimana potensi ketersediaannya di Kelurahan Limau Manih cukup besar. Pembuatan kompos itu sederhana dan mudah dipraktekkan asal mau, tekun dan memiliki inovasi. Untuk beralih ke pupuk organik ini perlu sosialisasi terus menerus karena petani telah terbiasa menggunakan pupuk kimia yang bersifat instan.

Pupuk kompos dapat berasal dari sampah organik yang telah mengalami dekomposisi akibat adanya interaksi mikroorganisme di dalamnya. Bahan-bahan organik yang digunakan antara lain dedaunan, rumput, jerami, kotoran hewan dan sampah (Purwo, 2007)[3]. Kompos merupakan pupuk organik hasil dari pelapukan jaringan atau bahanbahan tanaman atau limbah pertanian. Untuk mempercepat pembuatan kompos Warnita et al (2014) [14] menggunakan EM-4 dalam pembuatan kompos thitonia. Disamping itu untuk pembuatan kompos dari jerami padi dapat digunakan trichoderma sp.

Penempatan mahasiswa KKN-PPM di lokasi akan menjadi motivator dan penggerak 
dalam mengatasi masalah yang ada di masyarakat. Mahasiswa KKN-PPM akan menjadi motivator dalam menggerakkan pihak terkait untuk mengatasi permasalahan ketersediaan pupuk dan budidaya tanaman. Program KKN-PPM ini dilaksanakan dengan metode partisipatif dan aksi pada kelompok masyarakat sasaran.

Tujuan kegiatan pengabdian kepada masyarakat melalui KKN-PPM adalah untuk mendorong empati mahasiswa dan dapat memberikan sumbangsih bagi penyelesaian persoalan yang ada di masyarakat salah satunya adalah dengan mengaplikasikan hasil-hasil penelitian untuk meningkatkan hasil cabai merah dalam pot.

\section{METODE PELAKSANAAN KEGIATAN}

\section{Lokasi dan Tempat}

Kegiatan pemberdayaan masyarakat dengan melibatkan mahasiswa KKN-PPM dilaksanakan di Kelurahan Limau Manih Kecamatan Pauh Kota Padang. Kegiatan dilaksanakan dari bulan April sampai dengan Oktober 2017.

\section{Bahan dan Alat}

Bahan yang digunakan adalah bibit tanaman cabai merah, media tanam berupa tanah, pasir, pupuk kandang sapi, sekam dan kompos. Alat yang digunakan antara lain karung, cangkul, sekop, pot, polibag, alat tulis dan camera.

\section{Metode Pelaksanaan}

Tahap awal dilakukan analisis situasi dan permasalahan yang dihadapi oleh masyarakat. Penyelesaikan permasalahan yang dihadapi masyarakat khususnya petani dilakukan melalui transformasi ilmu dan teknologi (IPTEK). Berdasarkan kesepatan antara tim dengan mitra untuk mengatasi salah satu masalah yang dihadapi petani, dilakukan melalui metode penyuluhan, pelatihan dan demontrasi budidaya tanaman cabai merah dalam pot.

Metode kegiatan yang dilakukan dalam pemberdayaan kelompok sasaran adalah dengan metode partisipasif dan aksi yang melibatkan ibu-ibu anggota KWT Tunas Harapan. Dalam kegiatan ini mahasiswa KKN-PPM bertindak sebagai fasilitator. Materi pada saat penyuluhan, pelatihan, dan pendampingan diberikan melalui pembelajaran orang dewasa (andragogi), dengan rasio $30 \%$ teori dan $70 \%$ praktik. Pembelajaran bagi orang dewasa harus sesuai dengan prinsip- prinsip dasar pembelajaran orang dewasa. Prinsip-prinsip tersebut seperti nilai manfaat, sesuai dengan pengalaman, sesuai dengan masalah yang dihadapi, praktis, sesuai dengan kebutuhan, menarik, dan partisipasi aktif dalam belajar.

\section{HASIL DAN PEMBAHASAN}

\section{Profil Kelompok Sasaran}

Populasi masyarakat Kelurahan Limau Manih lebih kurang 5.000 jiwa yang menempati 8 RW dan 17 RT. Lahan pertanian di daerah ini cukup luas, tetapi karena berada di sekitar kampus cendrung 
terjadi mutasi lahan yang cukup besar menjadi perumahan, pertokoan dan perkantoran.

Komodiatas utama yang ditanam masyarakat adalah padi yang terkenal dengan varietas Cisokan Limau Manih. Selain itu petani juga menanam jagung, jagung manis, ubi-ubian dan tanaman hortikultura cabai merah, bawang merah dan sayuran lainnya.

\section{Pemberdayaan Masyarakat dengan Melibatkan Mahasiswa KKN-PPM}

Sebelum pelaksanaan kegiatan

pengabdian kepada masyarakat, pertama dilakukan rekrutmen mahasiswa calon peserta KKN-PPM sesuai dengan ketentuan yang sudah diatur oleh Universitas Andalas. Rekrutmen dilakukan terhadap mahasiswa dari beberapa Program Studi yang dapat menunjang kegiatan ini. Bagi mahasiswa yang terpilih sebagai peserta KKN-PPM sebanyak 30 oerang diadakan pembekalan agar mahasiswa paham apa yang akan dikerjakan selama melaksanakan KKN-PPM.

Selanjutnya tim pelaksana Pengabdian Kepada Masyarakat, mahasiswa peserta KKN-PPM bekerjasama dengan kelompok tani/masyarakat melaksanakan program. Salah satu kegiatan yang dilaksanakan adalah penanaman cabai merah dalam pot.

Pelaksana Unit KKN-PPM Universitas Andalas menetapkan jadwal pelaksanaan KKN-PPM untuk tahun 2017 dimulai pada tanggal 4 Juli - 13 Agustus 2017. Penyerahan mahasiswa peserta KKN-PPM dilakukan oleh Pimpinan Universitas ke Pemerintah Daerah. Prosesi penyerahan mahasiswa KKN-PPM untuk Kelurahan Limau Manih dilakukan oleh WR 3 Universitas Andalas kepada Pemerintah Kota Padang melalui Camat Pauh Kota Padang (Gambar 1).

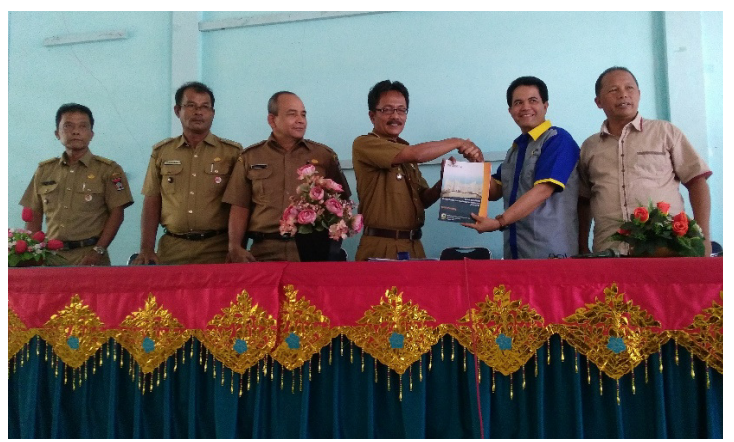

Gambar 1. Serah terima mahasiswa KKN PPM dari WR 3 Kepada Camat Pauh

Setelah serah terima mahasiswa diantar oleh Dosen Pembimbing Lapangan ke Kelurahan Limau Manih Kecamatan Pauh Kota Padang dan dilakukan acara serah terima dengan Bapak Lurah. Tempat penginapan mahasiswa selama pelaksanaan kegiatan KKN-PPM disediakan oleh masyarakat setempat. Selama pelaksanaan kegiatan KKN-PPM mahasiswa harus tinggal selama 24 jam di lokasi KKN-PPM.

Khusus untuk kegiatan penanaman cabai merah di dalam pot sebagai percontohan dilakukan pada Kelompok Wanita Tani Tunas Harapan.

\section{Pelaksanaan Kegiatan Penanaman Cabai Merah Dalam Pot}

\section{Penyuluhan}

Kegiatan penyuluhan dilakukan untuk memberikan pengetahuan kepada masyarakat 
mengenai budidaya cabai merah secara umum. Di perkotaan keterdiaan lahan untuk budidaya sangat terbatas, maka perlu dilakukan suatu cara yang memungkinkan kita dapat bercocok tanam. Lahan pekarangan yang terbatas dan sempit juga dapat digunakan untuk bercocok tanam, salah satunya adalah budidaya tanaman di dalam pot.

Pada kegiatan penyuluhan dijelaskan bagaimana membudidayakan tanaman cabai merah di dalam pot. Disamping itu juga dijelaskan mengenai persyaratan bibit yang ditanam, media yang digunakan dan teknik pemeliharaan tanaman cabai merah dalam pot.

Kegiatan penyuluhan diikuti oleh ibuibu KWT Tunas Harapan dan mahasiswa KKN-PPM Universitas Andalas. Ibu-ibu KWT Tunas Harapan sangat tertarik dengan kegiatan ini dan mengikutinya dengan serius. Dalam kegiatan ini juga diberikan bantuan berupa pot dan polybag untuk penanaman cabai merah dalam pot. Penyuluhan dan penyerahan pot kepada ibu ketua KWT Tunas Harapan seperti terlihat pada Gambar 2

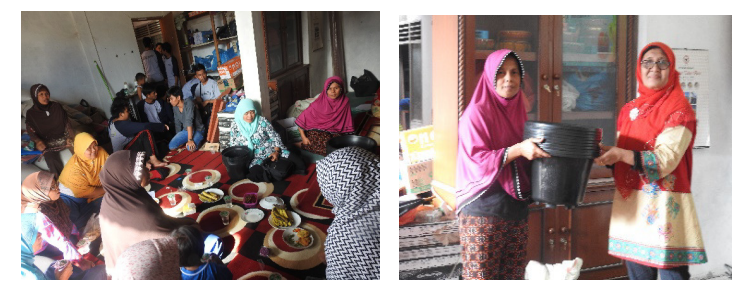

Gambar 2. Kegiatan penyuluhan dan serah terima pot kepada ibu - ibu KWT Tunas Harapan

\section{Pelatihan}

Pelatihan bertujuan agar mitra memahami apa yang akan dilakukan dalam budidaya tanaman cabai di dalam pot. Kegiatan pelatihan diawali dengan memberi penjelasan yang berkaitan dengan budidaya tanaman cabai merah dalam pot. Materi yang diberikan berupa media tanam yang digunakan, komposisi media, wadah tanam, dan faktor-faktor yang mempengaruhi pertumbuhan tanaman cabai merah dalam pot

Pada kegiatan pelatihan disediakan bahan dan alat yang dibutuhkan. Pembuatan media tanam cabai merah diawali dengan menyediakan media tanam seperti tanah, kompos, pasir dan sekam. Setelah itu dicampur menurut komposis yang ditentukan. Tanah, kompos dan pasir dicampur berdasarkan volume (v/v) 2:1:1, diaduk rata dan dimasukkan ke dalam pot.

Campuran media bertujuan agar media tidak terlalu gembur dan juga cukup mengandung hara. Pasir akan menyediakan pori yang cukup besar untuk pertumbuhan tanaman cabai merah, sementara kompos atau pupuk kandang sapi sebagai penggembur tanah dan penyedia hara. Netti et al (2015) [15] sebelumnya telah melakukan penanaman cabai merah dalam pot dengan komposisi media tanah : sekam : pupuk kandang; 1:1:1.

Pada kegiatan pelatihan dilakukan pencampuran dan pengadukan media tanam yang akan digunakan. Kegiatan pengadukan dan pencampuran media dapat dilihat pada 
Gambar 3.

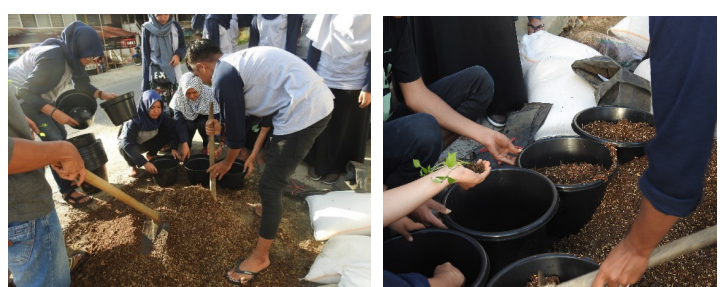

Gambar 3. Pengadukan dan pencampuran media tanam

\section{Demontrasi}

Dalam kegiatan ini mahasiswa peserta KKN-PPM sebagai fasilitator mendemontrasikan teknik budidaya cabai merah dalam pot dihadapan ibu-ibu anggota KWT Tunas Harapan. Wadah tanam yang digunakan berupa pot dan polybag.

Setelah media tanam tercampur rata sesuai dengan komposisinya dimasukkan ke dalam wadah berupa pot atau polybag. Setiap wadah ditanami 1 bibit tanaman cabai merah (Gambar 4)

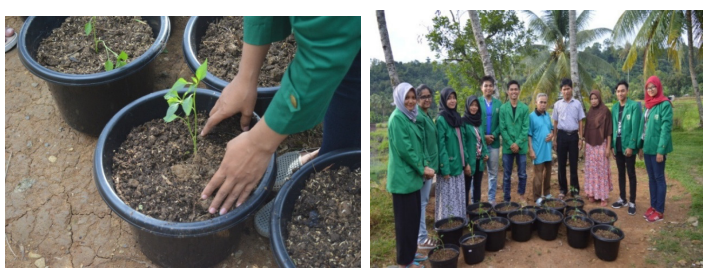

Gambar 4. Penanaman cabai merah dalam pot.

Penanaman cabai merah di dalam pot ini terbilang tidak terlalu sulit dan pemanfaatan lahan yang juga tidak terlalu luas. Penempatan cabai merah di dalam pot bisa dilakukan di dekat pagar atau di tepi selokan di sekitar rumah.

Untuk perawatan cabai merah di dalam pot atau polybag juga tidak terlalu sulit, cukup menyiramnya dengan air pada waktu pagi dan sore hingga mencapai kapasitas lapang, terutama pada saat proses pertumbuhan cabai merah sangat membutuhkan air. Tanaman cabai merah ini juga harus cukup terkena sinar matahari untuk pertumbuhannya. Penyiangan gulma dalam pot dilakukan secara manual dengan mencabut gulma yang ada. agar tidak ada persaingan dalam mengambil unsur hara di dalam tanah.

Dari demontrasi budidaya tanaman cabai merah yang dilkakun mahasiswa KKN-PPM bersama ibu-ibu KWT Tunas Harapan dan masyarakat Limau Manih telah tumbuh dan berkembang. Masyarakat sangat antusias dan dapat melihat sendiri pertumbuhanya dari demontrasi yang telah dilakukannya (Gambar 5). Pertumbuhan tanaman cabai merah di dalam pot cukup baik dan dengan harapan kegiatan positif ini dapat dilanjutkan oleh masyarakat sekitarnya.
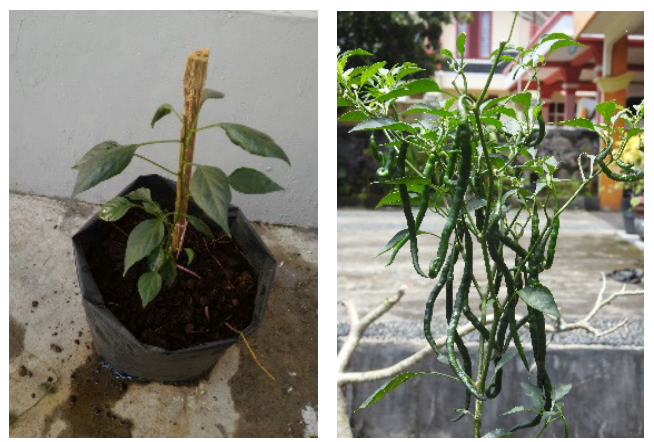

Gambar 5. Pertumbuhan tanaman cabai merah dalam pot

Hasil pengukuran kondisi pisik cabai merah di dalam pot dapat di lihat pada Tabel 1. Tinggi tanamaan, jumlah cabang dan jumlah daun bervariasi antara beberapa media yang digunakan. Pertumbuhan yang lebih 
baik dihasilkan oleh media tanah: pasir: kompos (2:1:1) dibandingkan dengan perlakuan yang lain.

Tabel 1. Tinggi Tanaman, Jumlah Cabang dan Jumlah Daun Tanaman Cabai merah di Dalam Pot dengan Media Tanam yang Berbeda

\begin{tabular}{|c|c|c|c|}
\hline Komposisi Media & $\begin{array}{l}\text { Tinggi Tanaman } \\
(\mathrm{cm})\end{array}$ & $\begin{array}{l}\text { Jumlah } \\
\text { cabang }\end{array}$ & Jumlah daun \\
\hline \multirow[t]{4}{*}{ Tanah : pasir : Sekam } & 35 & 4 & 90 \\
\hline & 40 & 3 & 80 \\
\hline & 38 & 3 & 75 \\
\hline & 42 & 4 & 80 \\
\hline \multirow[t]{4}{*}{ Tanah : pasir :Kompos } & 50 & 6 & 130 \\
\hline & 56 & 8 & 140 \\
\hline & 58 & 6 & 156 \\
\hline & 52 & 8 & 138 \\
\hline \multirow{4}{*}{ Tanah : pasir : Kotoran Sapi } & 41 & 5 & 118 \\
\hline & 45 & 5 & 120 \\
\hline & 43 & 4 & 121 \\
\hline & 46 & 4 & 130 \\
\hline
\end{tabular}

Media tanam tanah : pasir : kompos memperlihatkan pertumbuhan tinggi tanaman, jumlah cabang dan jumlah daun yang lebih tinggi dari kedua komposisi media lain. Sebelumnya Cayanti (2006) [16] menyatakan bahwa media mempengaruhi tinggi tanaman, jumlah cabang, waktu bunga pertama muncul, waktu buah pertama muncul, jumlah buah per cabang, jumlah bunga total, dan jumlah buah total. Media kokopit:tanah:pupuk kandang merupakan media yang terbaik untuk kualitas cabai merah hias dalam pot.

\section{KESIMPULAN}

Dari kegiatan pemberdayaan masyarakat melalui KKN-PPM ini dapat ditarik kesimpulan sebagai berikut :

1. Kegiatan KKN-PPM diikuti oleh 30 orang mahasiswa yang untuk kegiatan penanaman cabai merah dalam pot bermitra dengan KWT Tunas Harapan.
Kegiatan yang dilakukan adalah pembekalan, penyuluhan, pelatihan dan demontrasi.

2. Hasil yang telah dicapai dalam kegiatan ini adalah KWT Tunas Harapan dan masyarakat sekitar Kelurahan Limau Manih telah mamahami dan telah melaksanakan budidaya tanaman cabai merah dalam pot.

3. Pertumbuhan dan produksi cabai merah dalam pot juga bisa tinggi jika dilakukan dengan cara yang tepat.

4. Masyarakat memperlihatkan respon yang positif dalam kegiatan ini, terlihat dari partisipasi aktif dan antusias mereka mengikuti kegiatan dari awal sampai akhir pelaksanaan.

\section{UCAPAN TERIMAKASIH}

Ucapan terima kasih disampaikan kepada DRPM Kementerian Riset, Teknologi dan Perguruan Tinggi yang telah mendanai program KKN-PPM ini melalui Surat Perjanjian Pelaksanaan Pengabdian Kepada Masyarakat Skim KKN-PPM sesuai SPPK No. 012/SP2H/PPM/DRPM/IV/2017 tanggal 30 Maret 2017. Ucapan terima kasih juga kami sampaikan kepada Lembaga Penelitian dan Pengabdian Kepada Masyarakat Universitas Andalas, Pemerintah Kelurahan Limau Manih, Kelompok Tani Tunas Harapan, Kelompok Wanita Tani Tunas Harapan dan Gabungan Kelompok Tani Harapan Bersama, mahasiswa peserta $\mathrm{KKN}_{-}$ 
PPM, serta masyarakat Limau Manih umumnya.

\section{REFERENSI}

[1] Prayudi, B. 2010. Budidaya dan Pasca Panen Cabai merah (Capsicum annum L.). Badan Penelitian dan Pengembangan Pertanian, Balai Pengkajian Teknologi Pertanian, Jawa Tengah.

[2] Setiadi. 2005. Bertanam Cabai merah. Penebar Swadaya. Bogor. 183 hal.

[3] Purwo, 2007. Petunjuk pemupukan. Agromedia Pustaka. Jakarta. Hal 24 29.

[4] Sumarni, N. dan R. Rosliani. 2001. Media tumbuh dan waktu aplikasi larutan hara untuk penanaman cabai merah secara hidroponik. J. Hort. 11(4):237-243.

[5] Wuryaningsih, S., B. Marwoto, A. Mintarsih. 2001. Tanggapan klon krisan terhadap media tumbuh tanpa tanah. J. Hort. 11(2):76-85.

[6] Warnita, Swasti E, Muhsanati et al. 2015. Pengaruh media tanam terhadap pertumbuhan beberapa bibit tanaman hias. Prosiding Seminar Semirata BKS Barat Palangka Raya 20 - 21 Agustus 2015. Vol 1: 92 - 98.

[7] Warnita, dan Netti Herawati. 2017. Pengaruh konsentrasi Naphthalene Acetic Acid (NAA) dan pupuk daun terhadap pertumbuhan tanaman hias Anthurium 'gelombang cinta' (Anthurium plowmanii). PROS SEM NAS MASY BIODIV INDON Vol 3 (1): 69-74.

[8] Warnita, N. Akhir dan Vina. 2017. Growth Response of Two Varieties Chrysanthemum (Chrysanthemum sp.) on Some Media Composition. International Journal on Advanced Science Eenginering Information Technology. Vol 7 (3) : 928 - 934.

[9] Suarsi, T. K dan N. Andiani. 2013. Pertumbuhan Tunas Sansevieria trifaciata Prain 'Laurentii' pada Beberapa Komposisi Media Tanam dan Konsentrasi GA3. Bul. Agrohorti 1
(1) : $89-93$.

[10] Irawan, A dan Y. Kafiar. 2015. Pemanfaatan cocopeat dan arang sekam padi sebagai media tanam bibit cempaka wasian (Elmerrilia ovalis). PROS SEM NAS MASY BIODIV INDON Vol 1 (4) : 805-808.

[11] Balai Proteksi Tanaman Pangan dan Hortikultura (BPTPH) Provinsi Sulawesi Tenggara, 2010. Teknik Pembuatan Kompos dengan Menggunakan Agens Hayati. Leaflet. Laboratorium PHP Kendari. Margono dan Sigit. 2000. Pupuk Akar. Penebar Swadaya. Jakarta. 96 hal.

[12] Fatmawati. U. 2009. Potensi Kotoran Sapi. Http//www.wordpress.org. Diakses Tanggal 8 Juli 2012.

[13] Adijaya I N.dan P. Sugiarta. 2013. Meningkatkan produktivitas cabai merah kecil (capsicum annum) dengan aplikasi bio urin sapi. Seminar Nasional Inovasi Teknologi Pertanian. $583-590$.

[14] Warnita, Rozen dan Aisman. 2014. $\mathrm{I}_{\mathrm{b}} \mathrm{M}$ Upaya Peningkatan Produksi Ubi Kayu Organik Di Kecamatan Koto Tangah Kota Padang. Laporan IbM Universitas Andalas.

[15] Netti, H., Ardi, Warnita dan I. Ferita. 2015. Sosialisasi Pengembangan Tanaman Cabai merah dalam Pot. Laporan Akhir Kegiatan Pengabdian Kepada Masyarakat Fakultas Pertanian Universitas And.alas. 14 hal 